MJ感

The Medical Journal of Australia • 1914-2014 www.mja.com.au

Editor-in-Chief

Stephen Leeder, AO, MD, FRACP

Deputy Editors

Tatiana Janusic, MBBS, DPH, FRACGP

Wendy Morgan, MB ChB, MPH(Hons), FRACGP

Astika Kappagoda, MB BS, MPhil, PhD

Robyn Godding, MB BS, MPH, FRACMA

Christine Gee, BSc(Med), MBBS(Hons)

Diana McKay, FRANZCP, MHM, AFRACMA

Deputy Editor, Poetry and Fiction

Leah Kaminsky, MB BS, BA

Senior Assistant Editors

Elsina Meyer, BSc

Katherine McLeod, BSc(Hons)

Assistant Editors

Christine Binskin, BSC

Suzanne Habjan, BSc(Hons), PhD

Olivia Wroth, BVSC

Graeme Prince, BAppSc, BA(Hons), MA(Hons)

Sonya Chervonsky, BA

Scientific Proofreaders

Gita Sankaran, BSc, MIM, PhD

Kathryn Tuckwell, MB BS, BA(Hons)

Librarian Jackie Holman, BAComm(Info)

MJA Journalist/Careers Editor Cate Swannell, BA

Editorial Administrator Kerrie Harding

Editorial Assistant Zane Colling

Production Glenn Carter, Peter Humphries

Electronic Publishing

Peter Hollo, BSc(Hons), BA, LMusA

Publishing Assistant Wade Clarke, BAComm

\section{CONTACT THE MJA}

AMPCo House, 277 Clarence Street. Sydney,

NSW 2000. ABN 20000005854

Post: The MJA, Locked Bag 3030, Strawberry Hills,

NSW 2012. Tel: (02) 9562 6666. Fax: (02) 95626699.

mja@mja.com.au

\section{INSTRUCTIONS TO AUTHORS: https://www.mja.}

com.au/journal/mja-instructions-authors

ADVERTISING AND COMMERCIAL REPRINTS

Sales and Marketing Manager David Kelly

Commercial Manager Delores D'Costa

Bus Dev \& Senior Account Manager Mike Mata

Account Manager Sarah Lander

Advertising Coordinator Susantika Susantika

Tel: (02) 95626621.

advertising@mja.com.au, reprints@mja.com.au

\section{SUBSCRIPTIONS Jane Anderson}

Tel: (02) 9562 6617. subscriptions@mja.com.au

2014 Annual subscription (+ GST):

Individual: RRP A $\$ 410.00$ (new), A\$350.00 (renewal).

Institutions: on application.

The Medical Journal of Australia (MJA) is published on the lst and 3rd Monday of each month by the Australasian Medical Publishing Company Proprietary Limited (AMPCo), a wholly owned subsidiary of the Australian Medical Association (AMA). The statements or opinions that are expressed in the MJA reflect the views of the authors and do not represent the opinions or policies of the MJA or the AMA unless so stated. None of AMPCo, the AMA or any of its servants and agents will have any liability in any way arising from information or advice that is contained in the MJA. Although all accepted advertising material is expected to conform to ethical and legal

standards, such acceptance does not imply endorsement by the MJA. The MJA is intended for medical professionals and is provided without warranty, express or implied.

All literary matter in the MJA is covered by copyright, and must not be reproduced, stored in a retrieval system, or transmitted in any form by electronic or mechanical means, photocopying. or recording, without written permission.

(c) AMPCo, 2014 - Printed by Webstar Australia.

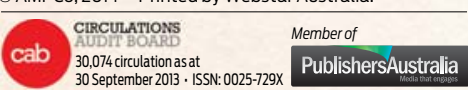

\title{
Highlights from our 1925 archives
}

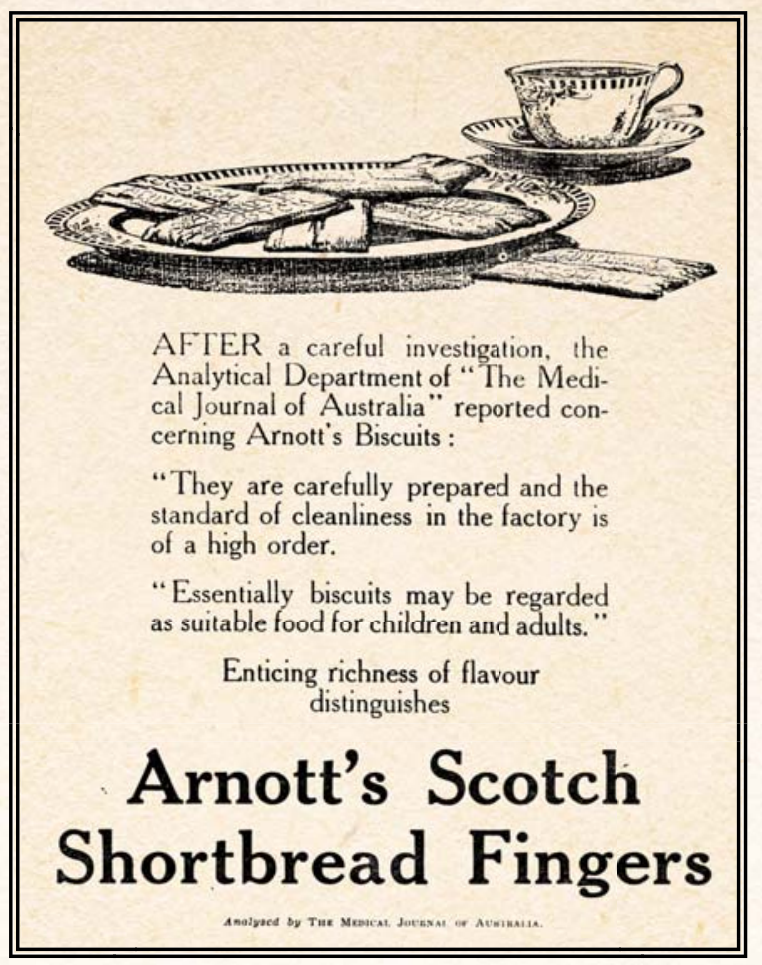

South Australian country practice for sale: Income over $£ 800$. May be considerably increased. Goodwill for sale to approved successor on terms, viz., $27 \frac{1}{2} \%$ of the first 2 years' income. Cash required for furniture $(£ 200)$ and drugs at valuation. The district is picturesque and healthy, the climate excellent and the residents financially sound. For further particulars apply to "MB" c/o The Medical Journal of Australia, 30-34 Elizabeth Street, Sydney.

\section{Overdoses}

Sir: During this week we received a prescription late in the afternoon which included a 25 minim dose of tincture of belladonna for repeated administration.

We endeavoured to get into touch with the prescriber who had left his rooms and who had not arrived home when the hour of legally compulsory closing approached. We dispensed the maximum legal dose and on the following morning advised the physician of what we had done. He took exception to our action and challenged our right to reduce his dose which was officially an overdose.

We pointed out that if he had initialled this overdose thus accepting responsibility for any possible untoward effect, we should not have hesitated to carry out his wishes. But until he is prepared to accept this responsibility and signify his acceptance in some manner capable of legal proof, we advised him that we were not prepared to take the risk of legal proceedings.

May we suggest that every member of the medical profession can always obtain the exact execution of his wishes if he will merely initial such overdose on his prescription?

H. Francis \& Co

280 Bourke Street, Melbourne 20 February 1925

\section{The perils of the popular press}

The daily newspapers seem to delight in publishing paragraphs and articles dealing with medical matters.

In Australia these paragraphs and articles are not submitted to competent medical practitioners for revision, with the result that save on quite exceptional occasions the news conveyed is misleading and often utterly absurd.

For many years The Times has employed a medical man of eminence who attends at Printing House Square every day to handle all medical and hygienic matters. It has been worth the proprietors' while to pay this medical correspondent a handsome retaining fee for this work and the result has been excellent.

In Australia newspapers have not recognised the advisability of paying for accuracy in technical matters of this kind. The public in consequence obtains an entirely false record of modern achievements in medical science and not infrequently suffers real damage as a result of sensational statements devoid of a reliable basis.

Science can be entrancingly interesting and fascinating, but it cannot be sensational.
It is necessary to counter this cheap form of journalism.

The daily newspapers also contain from time to time articles on medical subjects written and signed by medical practitioners. The General Medical Council has repeatedly warned doctors in active practice against this.

In recent times special attention has been directed toward this form of "oblique" advertising and a special notice has been issued, warning offenders that the GMC in Great Britain will remove their names from the medical register.

It is eminently desirable that the public should have reliable information on certain medical matters, but the greatest care should be exercised concerning the manner in which this information is conveyed. There are many pitfalls to be avoided and not the least of these is the boosting of hypotheses sponsored by one individual and not or not yet accepted by a substantial section of the medical profession. 